\title{
COVID-19 Vaccine: The War that Lies Ahead
}

\section{Vijay Dubey*}

Technology Transfer Department, MSD, Ireland

*Corresponding Author: Vijay Dubey, Technology Transfer Department, MSD, Ireland.

We all have seen the quote "Objects in the mirror are closer than they appear" on our vehicles but have you ever wondered how close the object actually is?

I am sure never, but when it comes to the discovery of a treatment or medical ailment, it does matter. Even the difference of a small inch can affect the whole process.

Today, the world is fighting against COVID-19 and various researchers are trying to discover the remedy to this problem. Most of them have already developed the vaccine and it seems like we are very much close to the solution to this pandemic.

But, the question is how close? Why is it taking so much time?

Are we lacking somewhere or are there any doubts about the development?

In my last post, I raised a question on life science and its failure to control the pandemic COVID-19. Let's continue with these questions. What is the bioscience industry doing to control this virus?

Let's shower some light over the assorted medical science firms which are acting on this modern-day pandemic.

A mix of legacy drug makers and small startups have stepped forward with plans to develop vaccines or treatments that focus on the infection caused by the novel coronavirus.

But, where do things stand?

To answer this, let's discuss one by one about these drug makers and where are they within the phase of development?

\section{Gilead Sciences Inc}

Gilead is testing Remdesivir (GS-5734), which is a novel medication developed as a treatment for Ebola virus and Marburg virus infection; although, it has subsequently shown antiviral activity against respiratory syncytial viruses like hemorrhagic fever virus, Nipah, MERS and SARS (a variety of coronaviruses). That's the rationale why Gilead is testing the identical treatment for this novel Coronavirus SARS- CoV-2 (COVID-19).
Received: March 20, 2020

Published: May 07, 2020

(C) All rights are reserved by Vijay Dubey.
The trial was given the go-ahead by China's Food and Drug Administration in February.

So, Gilead is conducting Phase -3 trials for its drug Remdesivir and expect results by May.

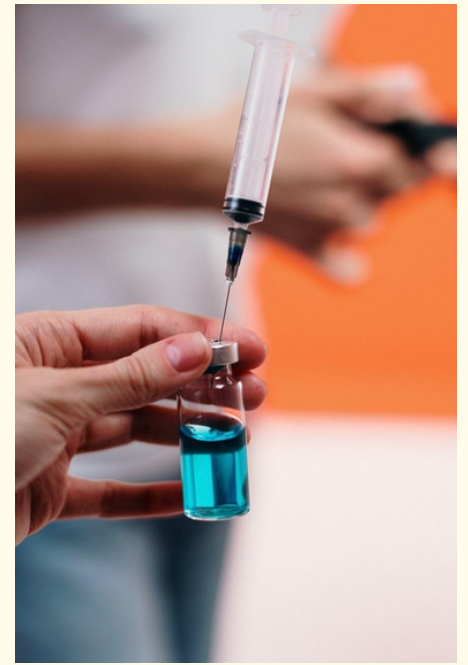

Figure 1

\section{GlaxoSmithKline}

GSK is functioning with a Chinese biotechnology company (Clover Biopharmaceutical Inc.) to develop a vaccine candidate COVID-19 S-Trimer employing a vaccine adjuvant platform technology, which is believed to both strengthen the response of a vaccine and limit the quantity of vaccine needed per dose.

Pre-clinical studies for this vaccine candidate were started by late February and further information has not been revealed yet.

\section{Inovio Pharmaceuticals Inc}

The COVID-19 vaccine, INO-4800, developed by Inovio pharmaceutical isn't like most of the killed or weakened variety of the 
virus. But it's a vaccine with the genetic instruction to form just a fraction of a virus or DNA vaccine which is able to help in generating the immune reaction in humans.

Preclinical testing for INO-4800 was performed between 23 January and 29 February. Clinical trials for this vaccine will begin within the U.S. with 30 participants in April. It also plans to launch human trials in China and South Korea during the same month.

Inovio is going to be the primary company with results from the trial within the fall and it will own 1 million doses of the vaccine ready for added clinical trials or emergency use by the end of the year.

\section{Johnson and Johnson}

On 11 February, J\&J said it's working with BARDA to check its vaccine candidate, with both organizations providing funding for research and development and also the public-health organization funding the Phase 1 trials.

The company aims to begin a Phase 1 clinical test by the top of 2020, compared to the standard five to seven years it takes for this milestone in vaccine development.

\section{Moderna Inc}

Moderna is developing an RNA-based vaccine candidate. Moderna received funding from CEPI on 23 January to develop an mRNA vaccine against COVID-19. On 24 February, they shipped the primary batch of mRNA-1273 to the NIAID for a Phase 1 clinical test within the U.S.

An open-label \{phase I\} clinical trial for mRNA-1273 will begin from Saint Joseph day. The trial is predicted to conclude on 1 June 2021.

But a recent report by Moderna reveals that the unique design of the vaccine is allowing Moderna to fast-track the development process because the company didn't have to isolate and modify live samples of SARS-CoV-2. But Moderna has not put this technology to test before; the corporation is yet to bring such a vaccine to market.

They are assuming the strategy works, though, speeding through animal testing may prove to be a good decision, especially within the context of this pandemic. While taking shortcuts may speed up the vaccine development process, it's uncertain how much time will it save in the long term?

\section{Regeneron Pharmaceuticals Inc:}

Regeneron has announced it's acting on developing monoclonal antibodies as treatments for COVID-19. They're planning to have many thousands of prophylactic doses ready for human testing by the end of August.

They are currently proceeding with pre-clinical studies for the treatment.

Sanofi

Sanofi is functioning with BARDA to check a preclinical vaccine candidate for the severe acute respiratory syndrome (SARS) for COVID-19 using its deoxyribonucleic acid platform.

Sanofi aims to place a vaccine into a Phase 1 clinical test between March 2021 and August 2021.

\section{Takeda Pharmaceutical Company Ltd}

Takeda is one of the foremost recent entrants to the race to develop a treatment for COVID-19.

The Japanese drug maker is progressing to test hyperimmune globulins for people that are at high risk for infection with their new treatment TAK-888.

\section{Vir Biotechnology Inc}

Vir has collaborated with Shanghai-based WuXi Biologics to check monoclonal antibodies as a treatment for COVID-19.

They are currently in their pre-clinical stage and if the treatment is approved, WuXi will commercialize it in China, while Vir will have marketing rights for the remainder of the globe.

There are some other organizations working on the development of the COVID-19 vaccine.

CureVac

CureVac - the German biotech at the centre of a Donald Trump acquisition rumour - has received a grant from the European Commission to speed up the development of a plant set to make a potential mRNA antibody against coronavirus.

mRNA antibody platform developed by CureVac is based on their in-house nucleotide sequence library and its carrier molecule: lipid nanoparticle (LNP) developed in collaboration with Acuitas and Arcturus Therapeutics; and its own CureVac carrier molecule (CVCM).

The phase 1 trials for the treatment are expected to begin this summer. 


\section{Conclusion}

Based on all this information, it is quite evident that most of the treatments will be available either on the top of this year or later. But, don't you think it will be too late?

Yes, it will be late, but these are the only options we are left with. A drug or vaccine development is not only about developing a drug in the lab. It constitutes various clinical studies, small scale development, transferring of these technologies to a large scale, drug filing, audits, approvals and of course, a large amount of money.

Most of the companies are now jumping directly into the volunteer Phase 1 trial by utilising the information gathered during the study of other strains of COVID-19 (SARS and MERS).

These studies are helping the organizations in moving on at a pretty fast pace on different stages after development. But still, it will be six to eight months until a vaccine could become available in the market. And believe me, this is the shortest time we can count on the availability of vaccines in the market as per the vaccinology field.

But if we see the current scenario, it's still too late.

To be honest, we were not prepared for this pandemic. This COVID-19 has highlighted thousands of areas where countries and companies were falling short of optimacy.

We were short of resources and most importantly a lack of plan $B$ in case of these emergencies. Coronavirus has shown the world how important science is for the survival of mankind. Let's learn from this incident and start investing more in science and scientists - disproportionately, provocatively and unimaginably higher than what we are doing right now.

The future wars will have scientists fighting in laboratories and machines on the field. This is a great lesson that Coronavirus teaches us. Time for nations to realign their priorities and for the societies, the pecking order.

This is the reason why people are buying a share of these companies. Buying a share now at a cheap rate will give them a longterm return after the vaccine or treatment is out in the market.

"If all the members of the whole innovative biopharma ecosystem come together, we'll be best positioned to address the crisis".

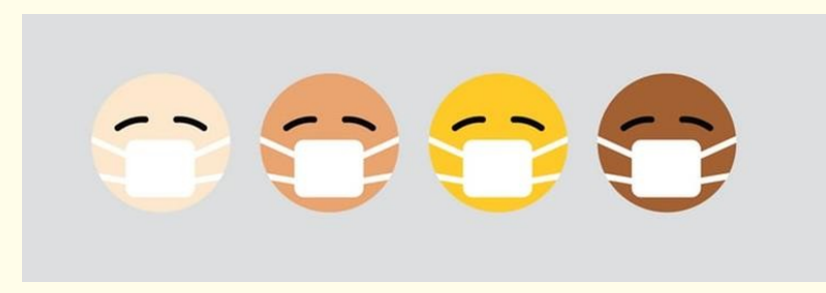

Figure 2

\section{Assets from publication with us}

- Prompt Acknowledgement after receiving the article

- Thorough Double blinded peer review

- Rapid Publication

- Issue of Publication Certificate

- High visibility of your Published work Website: www.actascientific.com/

Submit Article: www.actascientific.com/submission.php Email us: editor@actascientific.com

Contact us: +919182824667 